\title{
薬学的介入の医療処置への反映度に基づいた新しい薬剤管理指導業務評価法の開発
}

\author{
井出直仁, ${ }^{*, a}$ 後藤誠一, ${ }^{a}$ 森 雅 美 $^{b}$
}

\section{Proposal for a New Tool to Evaluate Clinical Pharmacy Practice Based on the Percentage of Pharmaceutical Interventions that Influence Medical Treatments}

\author{
Naohito IDE, ${ }^{*}, a$ Seiichi Gotou, ${ }^{a}$ and Masami MORI ${ }^{b}$ \\ ${ }^{a}$ Department of Pharmacy, Kakegawa City General Hospital, 1-1-1 Sugiya-minami, Kakegawa City \\ 436-8502, Japan, and ${ }^{b}$ Nagoya City University School of Nursing, 1 Kawasumi, \\ Mizuho-chou, Mizuho-ku, Nagoya 467-8601, Japan
}

(Received January 17, 2008; Accepted May 1, 2008)

\begin{abstract}
Clinical pharmacy practice needs quality safeguards and proper evaluation to ensure good performance of hospital pharmacists. We propose a method for evaluating performance using the indicator of whether pharmaceutical interventions conducted in clinical practice affect the treatment carried out by the physician. To illustrate the usefulness of this method, we report one example of the response of a physician to our clinical practice. We first designed a worksheet on which information related to pharmaceutical interventions would be recorded. The worksheet included sections for the details of the pharmaceutical intervention, whether decisions about interventions were active (pharmacists' decisions) or passive (requests from the physician), the timing of the intervention (before or after prescription), the grounds for the intervention, and whether it had any influence on the treatment, as well as a detailed record of the course of the intervention. These worksheets were used to record pharmaceutical interventions from July to December 2005. During that period, a total of 347 pharmaceutical interventions for 164 patients were recorded. Each intervention was examined from the different perspectives of type of intervention, timing (before or after prescription was issued), and reason for the intervention. Overall, it was found that $91.6 \%$ of all interventions had some influence on treatment. Because numerical results can be obtained with this method, it has the benefit of being an objective means of evaluating the contribution of pharmaceutical services. Furthermore, the validity of even those interventions that had no influence on treatment can be examined using medical and pharmaceutical findings and may improve the quality of pharmacists.
\end{abstract}

Key words_— clinical pharmacy practice; evaluation; pharmaceutical intervention; medical treatment

\section{緒言}

掛川市立総合病院（以下，当院と略す）では 1994 年 12 月から, 全病棟において 60 床の病棟毎 に薬剂師 1-2 名を配置して薬剤管理指導業務の実施 に取り組む体制を採った，当初は，業務内容の構築 とその遂行に追われる毎日であったが，数年後には ルーチン化して一定の算定件数が確保される状態に なった.

経営面からは薬剤管理指導業務の質は問題とされ ず，算定件数だけに目が向けられる．薬剤管理指導 業務の実施では，患者の状態・既往歴を把握した上 で，薬歴・相互作用・臨床検査值・副作用モニタリ ング・薬物血中濃度の值の確認など，いわゆる薬学

$a$ 掛川市立総合病院薬剤室, $b$ 名古屋市立大学看護学部

*e-mail: prunus_mume_2@bridge.ocn.ne.jp
的観点から患者治療に関与することが求められる. 換言すれば，一部で実施されている「薬の説明」だ けであってはならないことは論を待たない，

薬剤師の臨床業務の有用性が報告され，1）その後 も薬剂管理指導業務の質の担保とその評価が数多く 論じられている. ${ }^{2-7)}$ 薬剂管理指導業務の根幹をな す薬剤師の行為一いわゆる薬学的介入一は，それら が医療行為に反映されてこそ意味あるものであり, 介入の頻度の数の多寡を論じても本質を捉えるもの ではないと考える，今回は，薬学的介入の質を医師 側の目から評価する手法の開発を試み，薬学的介入 内容が治療行為にどの程度反映されたかをもつて薬 剂管理指導業務の質的評価を行ったのでここに報告 する. 


\section{方法}

1. 薬学的介入記録表（ワークシート）の作成 （Fig. 1）介入事例毎に診療科及び主治医名とと もに薬学的介入の内容及び介入時期あるいは介入に 至る背景などを記載することとした。薬学的介入の 内容は，若杉らの報告6)を参考とし，1）用法・用 量，効能・効果，2）薬物治療に関する提言，3）副 作用，4）相互作用，5）重複投与，6）過量 - 過少 投与，7）腎障害時の投与量，8）採血依頼（薬物血 中濃度測定依頼, 生化学検查などすべての採血を含 む），9）処方ミス，10）その他に分類した。さら に，情報提供行為が薬剤師側から（この場合は「能 動」とする）か，医師からの相談・依頼（この場合 は「受動」とする）か，薬学的介入は処方前か処方 後か，介入するに至る根拠が何であるか（薬物血中 濃度值，臨床検査值，薬歴，患者の訴えによる情
報，添付文書や成書の情報），薬学的介入に対する 医師の対応（薬剂師の意見が医療行為へ反映された 場合を反映あり，されなかった場合を反映なし)， さらに患者指導の経過を記載できるようにした。な お，ワークシートの大きさは A4 判とした.

2. 調査期間及び対象患者など 調査期間は平 成 17 年 7 月から平成 17 年 12 月までの 6 力月間 で, 循環器内科・内分泌内科の患者を中心とした病 棟（60 床）で薬剤管理指導業務を施行した患者を 対象とした。本調查期間における延べ入院患者数は 765 名，薬剂管理指導業務施行患者数は 631 名で, 薬剂管理指導料請求件数は 1011 件であった。

3. 統計処理 統計学的な分析は, 解析ソフト Statcel2（オーエムエス出版 MS Excelアドインソ フト）を使用し， $\chi^{2}$ 検定を行って判定した.

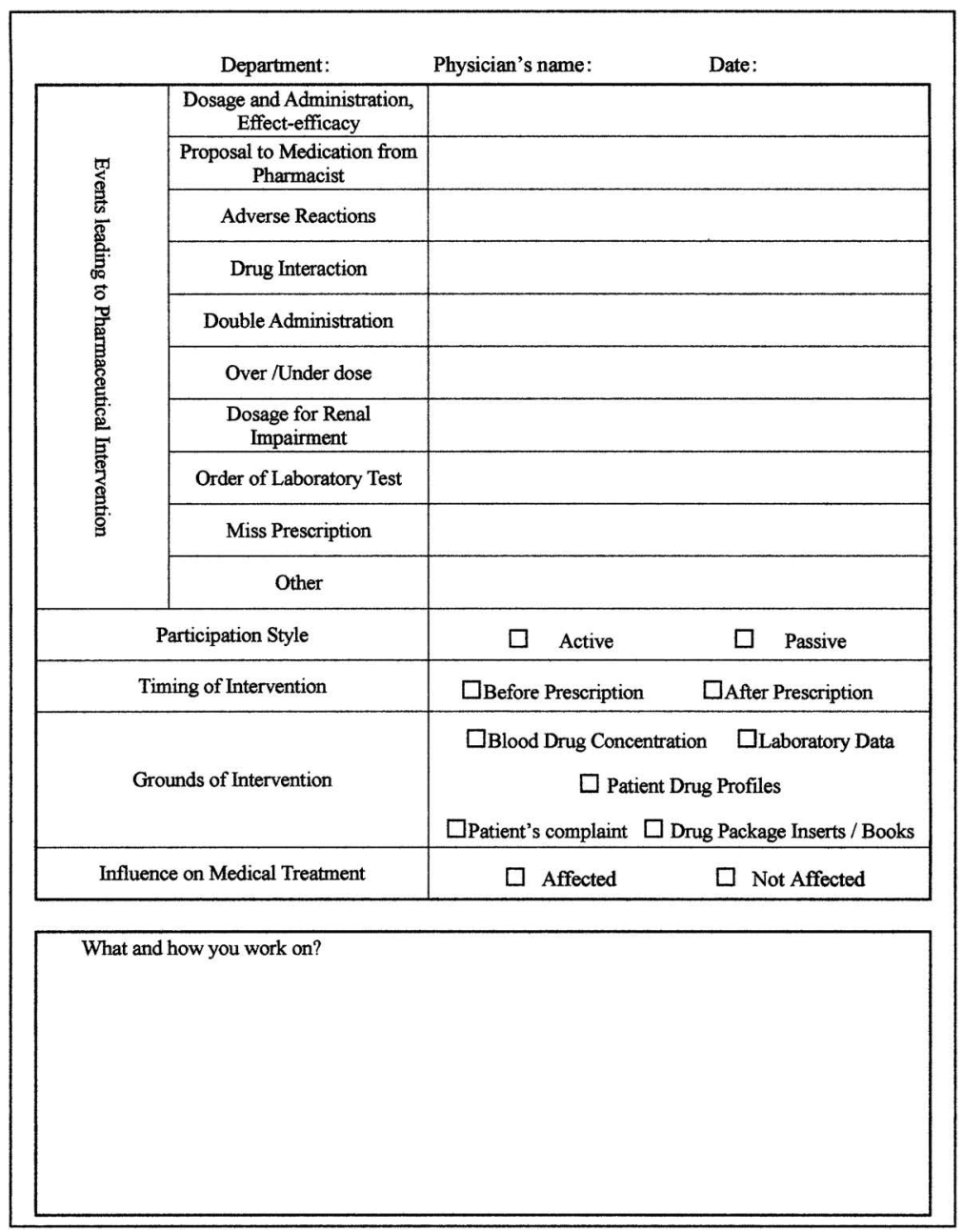

Fig. 1. Pharmaceutical Intervention Record Sheet 
結 果

1. 項目別の介入件数（Fig. 2） 半年間の薬剤 管理指導において，薬学的介入のあった患者数は 164 名（指導患者数の $26 \%$ ), 介入件数は 347 件 （指導件数の $34.3 \%$ ) であった。それらを以下のよ うに分類した。

介入件数が最も多かった項目は，「薬物療法への 提言」の 164 件であり，それらの治療への反映率は 91.5\% と高率であった。ついで件数が多かったもの は「採血依頼」の 58 件であり，これらに対する反 映率も $93 \%$ と高かった。「副作用」に関しては 33 件であったが，その反映率は $78.8 \%$ であった。続 いてホスフルコナゾールやテイコプラニンのローデ イングドーズ，あるいはステロイドの点滴から内服 への用量換算法など用法・用量・効能・効果に関す る項目が 26 件（反映率 $92.3 \%$ ），処方ミスの指摘 (23 件， $100 \%)$, 腎障害時の投与量変更の介入（13 件， $92.3 \%$ )，薬物相互作用 (10 件， $90 \%)$ ，重複 投与の指摘 $(8$ 件, $100 \%)$, 過量・過少投与の指摘 （5 件，100\%）であった。ささらに，「その他の項目」 が 7 件 $(100 \%)$ であった。「その他の項目」の事例 としては，医師が内服薬とは異なる薬物の濃度測定 オーダーを出したものの訂正や，朝の内服薬が多い 患者での夕食服用への変更提言などであった.

2. 関与形態と介入時期からみた薬学的介入の分 析関与形態が「能動」か「受動」かに分けて介
入事例を分析した，その結果，医師からの依頼を受 ける前に薬剤師の判断で実施したケース（能動）は 259 件 $(74.6 \%)$ であった。またそれらが医療行為 に反映された割合は $88 \%$ であった。他方，医師か らの依頼を受けてから対応したケース（受動）は 88 件（25.3\%） あり，それらが医療行為に反映さ れた割合は $100 \%$ あった。

次に，介入時期が処方前であるか処方後であるか に分けて事例を分析した，処方前の介入は 101 件 (29.1\%）であったのに対して，処方後に介入した 件数は 246 件 $(70.9 \%)$ と倍以上であった。それぞ れの治療への反映率は，処方前が $95.0 \%$ ，処方後 が 90.2\%であった.

3. 介入のきっかけ・根拠とそれらの件数 薬 学的介入実施例について，介入するに至る根拠別に 分類した結果を Fig. 3 に示した。根拠として最も 件数が多かったのは，「薬歴」に由来した介入で, 125 件（36.1\%）あった。それらの治療への反映率 は 95.2\%と高かった。ついで「患者からの訴え」 に由来した介入の 108 件 $(31.2 \%)$ で，それらの治 療への反映率は $89.8 \%$, 続いて「検査値」由来の 介入の 81 件 $(23.4 \%)$ で反映率は $87.7 \%$ ，「薬物血 中濃度」由来の介入 24 件 $(6.9 \%)$ で反映率は 95.8 $\%$,「添付文書・成書」由来の介入 8 件 $(2.3 \%)$ で 反映率は $100 \%$ の順となった。

4. 処方薬剤別の介入件数 処方された薬剂を 日本標準商品分類番号の薬効分類に沿って分類し,

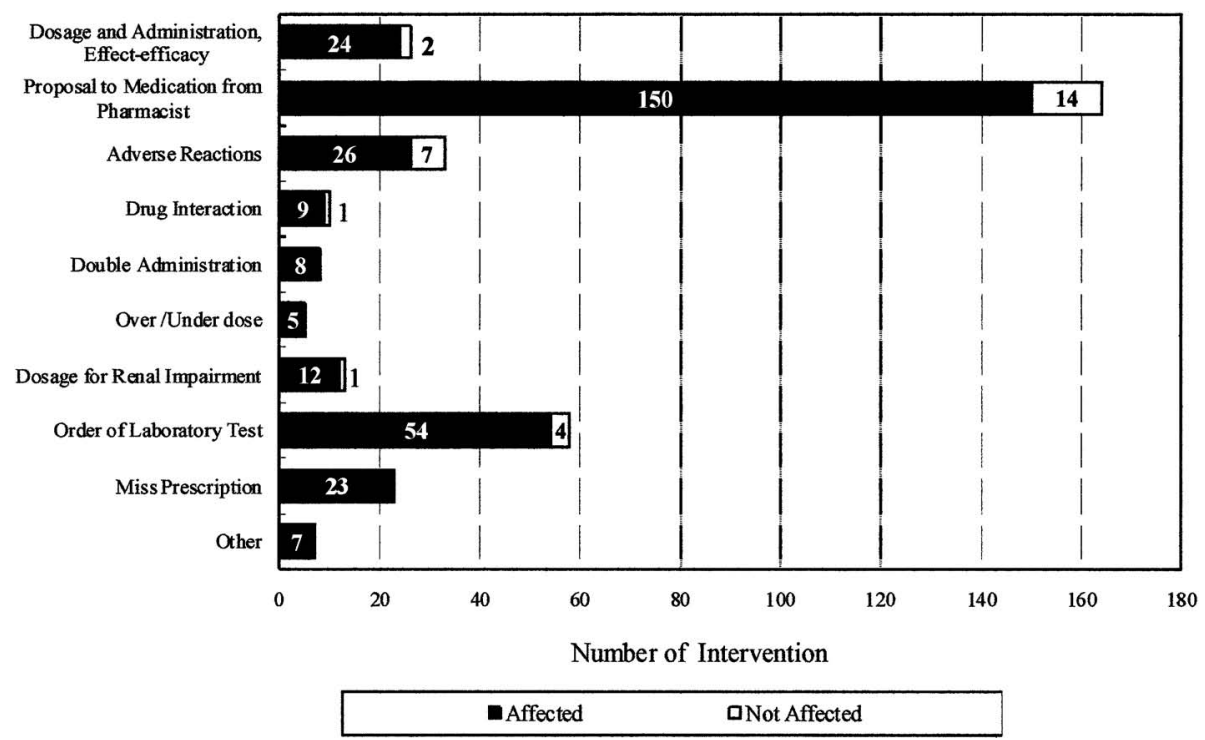

Fig. 2. Number of Pharmaceutical Interventions by Type 


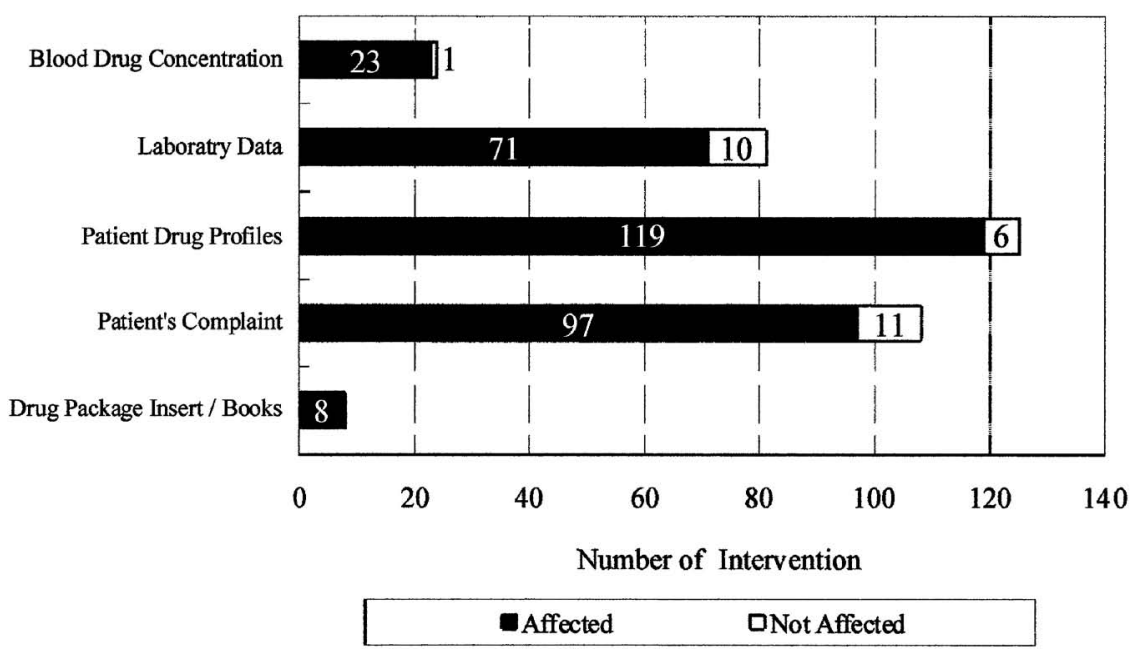

Fig. 3. Reasons for Pharmaceutical Interventions, and Number of Interventions for Each

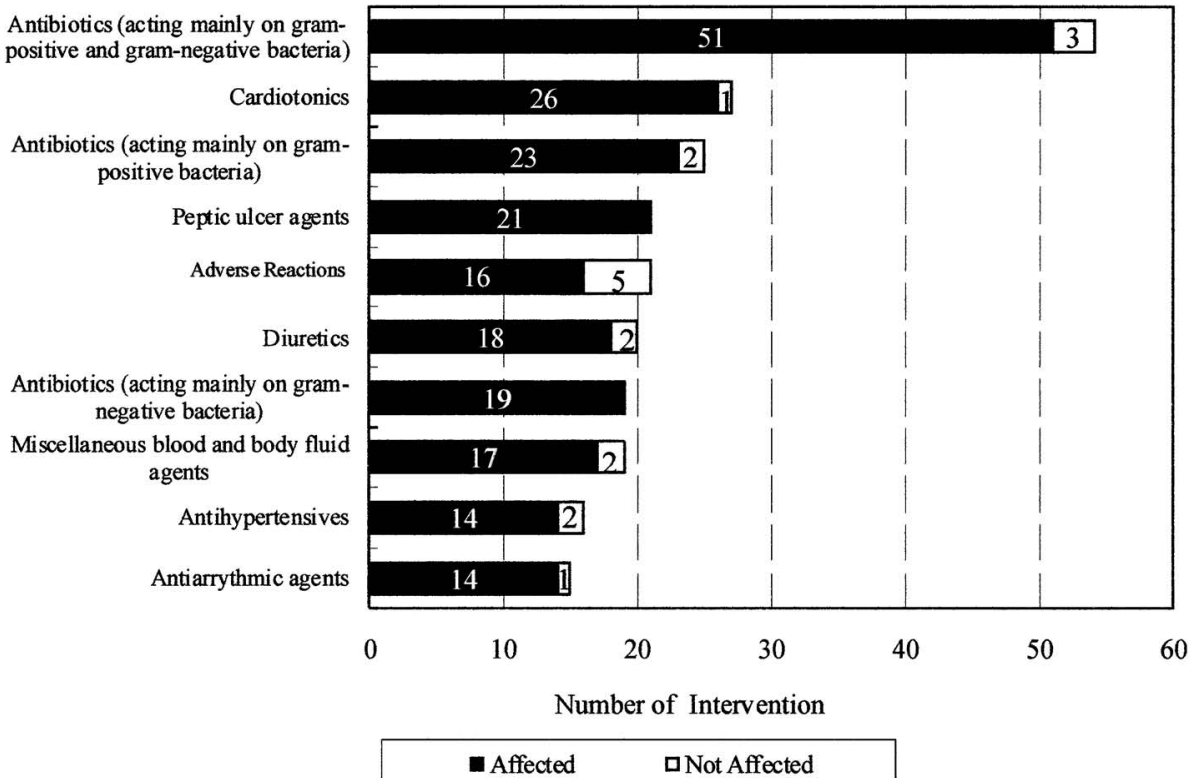

Fig. 4. Number of Pharmaceutical Interventions with Each Type of Medicine

それぞれに対する介入件数を求め, 件数の多かった 10 項目についてその結果を Fig. 4 に示した。「抗生 物質製剂：主としてグラム陽性菌・陰性菌に作用す るもの」に由来する介入が 54 件と最も多く，これ らの介入に対する治療への反映率は $94.4 \%$ と高か つた。ついで強心剤（27 件），抗生物質製剤：主と してグラム陽性菌に作用するもの（25 件），消化性 潰瘍剤 (21 件)，血液凝固阻止剤（21 件），利尿剤 (20 件), 抗生物質製剤：主としてグラム陰性菌に 作用するもの（19 件），その他の血液・体液用薬 (19 件), 血圧降下剤 (17 件), 不整脈用剤 (15 件),
抗てんかん薬（12 件)，血液代用剤（11 件）と続い た.

$$
\text { 考察 }
$$

1. 薬剤師業務の評価基準とプレアボイド＼cjkstart病 院薬剂師は薬剤管理指導業務を通じて医薬品の適正 使用並びに安全で良質な薬物治療の提供に貢献する ことが職務である，今回，薬学的介入について項目 別，関与形態別，介入時期別，介入根拠別，薬剂別 に件数と反映率を調査してファーマシューティカ ル・ケアの実践度の評価をした. 
現在，病院薬剤師業務の質を評価する公の方法と してプレアボイド報告が挙げられる。プレアボイド 報告は薬剂師業務が安全な薬物療法にいかに貢献で きているかを関係者に認識させる上で有用である. そうした活動に寄与することは薬剤師業務の質を担 保する上で有用であり，プレアボイド報告数の多寡 は個々の薬剤師の能力の質的な評価に有用である. しかし，薬剤師業務全体を評価する上ではかならず しも適切に機能していないと考える，筆者らは，本 調査期間において 25 件のプレアボイド報告（重篤 化回避事例 12 件，未然回避事例 13 件）を行った が，その数は当該期間中の薬剤管理指導業務中に行 つた薬学的介入の総件数の 347 件に対して $7 \%$ 程度 であった。具体的な例として重篤化回避事例はメロ ペネムやピペラシリンによる肝機能障害の早期発 見，ジスチグミン臭化物によるコリンエステラーゼ 低下の早期発見，未然回避事例はランソプラゾール とファモチジンの重複回避などがあったが，これら の事例のようにプレアボイド報告はあくまで有害事 象を未然に防いだり重篤化を回避した事例の報告で あり，今回の調査で行った「重複投与」や「副作用」 に関する項目はこれに含まれるが，「薬物療法への 提言」など，処方設計の段階において医療行為に薬 剂師の提言が反映されていることを評価することは できない.

\section{2. 薬学的介入記録表（ワークシート）の有用性}

薬剂管理指導業務実施の際, 薬剂師の行う各種の 薬学的介入が，医師側の行為にどのように反映され るかを把握することは，薬剤管理指導業務の本質に 迫る評価となる。今回作成したシートには，薬剤管 理指導実施中に行う標準的な介入事項が網羅されて いるため，薬剤管理指導業務の質的評価につなが り，業務遂行時の介入のきつかけを提供することと なる．また，業務終了時の総括を行う際にも活用で きる.さらに，介入事項が医療行為にいかに反映さ れたかあるいはされなかったかが把握できるため, 介入内容の適切性を検証する際の有用な資料となる.

\section{3. 介入項目の程度とそれらの反映度 介入項} 目では「薬物療法への提言」の件数が最も多くあり, しかもそれらは治療への反映率も高かった。 反映率 が高い背景として，薬剤師が病棟に常駐する体制を 採っており患者の状態や治療方針を把握した上で チーム医療の一員として治療に係わっている実績の
表れと考える．ついで件数が多い介入項目が「採血 依頼」である。その理由として，調査対象の病棟が 循環器内科の患者を主としているために, 強心配糖 体や抗不整脈薬のように薬物血中濃度の把握を必要 とする薬剤が多く使用されていることと，薬剤師側 から日頃アミノ配糖体抗生剂や抗 MRSA 薬が適正 使用されるには薬物血中濃度測定（TDM）が必要 であることを伝えてきたゆえであると考える，薬学 的介入として TDM を具申する際，大半のケースで 医師は受け入れ，その反映率は $93.1 \%$ と高かっ た. 医師側もTDMの重要性を認識してきた結果で あると考える．今後は米国でも認められているよう に，日本においても薬剤師に採血オーダー権が与え られるようになるべきと考える. ${ }^{8}$

副作用に関する介入は 33 件（全体の $9.5 \%$ ） と 項目別では 3 番目に多かったが，その治療反映率は 78.8\%で他の項目に比べると低かった。こうした結 果は，副作用を惹起する原因薬剤の特定が容易でな いためと考えられる．日頃の業務において薬凨師が 常に配慮している「相互作用」,「重複投与」, 「過量・ 過少投与量」あるいは「腎障害時の投与量の調節」 などは予期した件数よりも少なかった。いずれも反 映率は高かったが，「相互作用」ではメチルジゴキ シンとジソピラミドを併用した際に徐脈傾向にあり メチルジゴキシンの減量を提案した事例，「腎障害 時の投与量の調節」の介入ではクレアチニンクリア ランスが $20 \mathrm{ml} / \mathrm{min}$ と予想される患者におけるレ ボフロキサシンの投与量減量を提案した事例とそれ ぞれ 1 件ずつ受入拒否があつた点は，医師の理解力 不足によるか薬剤師の説明能力不足によるのもかの 検討が必要である.

関与では, 薬剤師主導の「能動」が全介入の $74.6 \%$ と大半であった。 反映率を比べると，「能動 的介入」が $74.6 \%$ であったに対して，「受動的介 入」は $100 \%$ と有意差を持って高值であった（ $p<$ 0.01). また, 医師の処方前と処方後の比較では, 処方後の介入が $70.3 \%$ 占めていた．医師の医療 行為へ反映された割合を「処方前介入」と「処方後 介入」で比較すると，前者は $95 \%$ ，後者は $90.2 \%$ となった. 件数の規模の違いから, 統計学的に両群 に有意な差はみられなかったが若杉らの報告同 様, ${ }^{6}$ 「処方後介入」よりも「処方前介入」の方が反 映率は高かった。このことが，薬剤師は「待ちの姿 
勢（処方後の介入）」でよいことを物語るものでは なくて，薬物療法を適切に進めるためには，処方設 計段階から薬剤師が積極的に関与することが必要と 考える.

介入根拠別の「反映有り」の件数は，「薬歴」に 由来する場合が 119 件で最も多く，ついで「患者か らの訴え」(97 件)，「検査值」（71 件），「血中濃度」 （23 件），「成書・添付文書」（8 件）であった。 反映 率でみると「患者からの訴え」は $89.8 \%$ であり, 「薬歴」の 95.2\%に比べて低值であったが，統計学 的には有意な差は認められなかった。また，「検査 値」の反映率 $87.7 \%$ は，「薬歴」の $95.2 \%$ に比べて 低かった $(p<0.05)$ ．これは検査值そのものにある 程度の許容の幅があるために直ちに治療方針の変更 （=反映あり）になる割合は低かったと考える。こ れは，薬歴あるいは薬物血中濃度のデータなどのよ うに薬学的根拠に基づくものは，医師も素直に受け 入れることを示している。この結果も若杉らの報告 と同じ傾向である. ${ }^{6}$ 当然であるが薬剤師の基盤と なる学問は「薬学」であり, 薬学的根拠に基づく介 入は治療反映率が高く, 薬学を学んだ薬剤師だから こそ可能な視点から個々の患者に相応した情報を提 供することが改めて重要であることを語っている。

薬剂別の介入件数の比較では，当該病棟の性質 上，強心剂，血液凝固阻止剂，利尿剂，血圧降下剂 などの循環器内科で汎用される薬剤がみられるのは 当然であるが，抗生物質関連の介入も多くみられ た。その要因の 1 つは，当院ではアミノ配糖体及び 抗 MRSA 薬が使用される際には薬物血中濃度測定 の実施をかならず依頼していることであるが，2つ 目の要因として，重症肺炎や感染性心内膜炎などの 疾患における抗生物質の選択について薬剤師の意見 を求められる例が多いからである，抗生物質は発熱 や炎症反応の上昇がみられた際に安易に使用される ことが多いが，耐性菌の発現からその適正使用が問 題となる．小茂田が中小病院の感染症対策における 薬剂師の役割を述べているが, 9 今回の結果から も, 感染制御において薬凨師の能力を必要とする部 分が多いと考えることができる.

4. 今回の評価法の妥当性と発展性 薬剤管理 指導業務が薬剤師の自己満足のためではないことは
自明であり，他職種からの評価も必要である。例え ば，田中らは薬剤管理指導業務に対する医師や看護 師の評価をアンケート法で分析・報告している. ${ }^{3)}$ しかし，アンケート法では医療内容への貢献度の把 握に限界がある。それに対して，今回の筆者らの評 価法では，薬剤師の行った個々の介入に対して医師 側の目で評価された結果が現れている。したがつ て，医療行為への反映度を客観的に捉えることが可 能となる点で優れている.

今回の調査研究で，薬学的介入を医師側が受入れ た割合（治療反映率）は全体で 91.6\%（318 件/347 件）と高かった。このことにより，既報の論文で報 告されているように, ${ }^{1-7)}$ 薬剤師の多くの提言が治 療に取り入れられ，それらの提言は薬学的根拠に基 づく介入であることが再認識できたといえる，当院 も例外ではなく, 該当病棟で行っている薬剤師の業 務が医師から高く評価されていると認識した。今後 は本シートをさらに改善，利用し有用性を高めてい きたいと考えている.

\section{REFERENCES}

1) Leape L. L., Cullen D. J., Clapp M. D., Burdick E., Demonaco H. J., Erickson J. I., Bates D. W., JAMA, 282, 267-270 (1999).

2) Kubo T., Kaji M., Tsuji S., Asakura M., Higuchi K., Mukai E., Tsukamoto T., Morita S., Yakugaku Zasshi, 121, 221-232 (2001).

3) Tanaka C., Kojima S., Kawai M., Med. Drug J., 37, 3353-3359 (2001).

4) Tanaka M., Orii T., Kawai N., Kondo Y., Yakugaku Zasshi, 122, 573-578 (2002) .

5) Ooi K., Katayama T., Fujioka M., Jpn. J. Pharm. Health Care Sci., 29, 107-110 (2003).

6) Wakasugi H., Nakagiri M., Ishii J., Kaneko I., Takahasi K., Yano I., Inui K., Jpn. J. Pharm. Health Care Sci., 29, 415-420 (2003).

7) Wakasugi H., Inui K., Pharm. Mon., 47, 1409-1416 (2005).

8) American Society of Health-System Pharmacists, Am. J. Health-Syst. Pharm., 56, 1665-1667 (1999).

9) Komoda M., Pharm. Mon., 48, 1369-1374 (2006). 